\title{
Canada and Terrorism: A Case Study
}

By Danny Barrett

\begin{abstract}
Despite an all-pervasive focus on terrorism, there is little critical discussion about its precise meaning or applicability to modern international relations. This paper seeks to examine Canada's role in relation to terrorism, by comparing official policy statements to the ways in which key government actors responded to a key, concrete example of international terrorism (the Israeli bombardment of Gaza in the winter of 2008-9). Based on the example discussed, the paper argues that contrary to official policy statements, Canada seems to offers firm support for international terrorism when it is committed by our allies.
\end{abstract}

"All nationalists have the power of not seeing resemblances between similar sets of facts. A British Tory will defend self-determination in Europe and oppose it in India with no feeling of inconsistency. Actions are held to be good or bad, not on their own merits, but according to who does them, and there is almost no kind of outrage - torture, the use of hostages, forced labour, mass deportations, imprisonment without trial, forgery, assassination, the bombing of civilians - which does not change its moral colour when it is committed by 'our' side. "- George Orwell ${ }^{1}$

In the West, it is widely agreed that we are living in an 'age of terror'. ${ }^{2}$ Curiously conspicuous in this focus on terrorism is that there have been few serious attempts to actually define the word and its applicability to modern international relations. American political writer Glenn Greenwald recently wrote that terrorism is "simultaneously the single most meaningless and most manipulated word in the American political lexicon."3 Echoing these sentiments, Noam Chomsky argues that there are two basic approaches to the study of terrorism: a literal approach: "determining what constitutes terrorism...then seeking instances of the phenomenonconcentrating on the major examples," and a propagandistic approach: "construing the concept of terrorism as a weapon to be exploited in the service of some system of power." While keeping the notion of the propagandistic approach in the back of our minds, this paper will focus on the literal approach to the study of terrorism and its relationship with Canadian foreign policy.

Canada's Foreign Affairs website states that "Canada believes that terrorism is a longterm global challenge...[w]e participate actively in the global fight against terrorism." Minister of Foreign Affairs Lawrence Cannon explains at the UN General Assembly that "Canada is committed to fighting terrorism and to holding the perpetrators

\footnotetext{
${ }^{1}$ Orwell, George. "Notes on Nationalism.” In The Decline of the English Murder (Penguin Books: Harmondsworth, 1946.) Pg. 165.

${ }^{2}$ Liberal leader Michael Ignatieff paid homage to this idea in the title of his widely acclaimed book: The Lesser Evil: Political Ethics in an Age of Terror. (Toronto: Penguin Books, 2004). Also See: Morden, Reid. "Spies Not Soothsayers: Canadian Intelligence After 9/11.” Commentary No. 85. Fall 2003.

${ }^{3}$ Greenwald, Glenn. "Terrorism: the most meaningless and manipulated word." Salon.com February $19,2010$.

${ }^{4}$ Chomsky, Noam. Pirates and Emperors, Old and New: International Terrorism in the Real World. (Between the Lines: Toronto, 2002.) pg. 119.

${ }^{5}$ Foreign Affairs and International Trade Canada. [http://www.international.gc.ca/crime/terrorismterrorisme.aspx?menu_id=30\&menu=R]
} 
and supporters of terrorism accountable for their actions." ${ }^{\prime 6}$ In a 2007 speech in Australia, Prime Minister Stephen Harper championed Canada's contribution to global solidarity against terrorism declaring that "both our countries have been bloodied by terror. And both of us are doing our part to confront and defeat it ... The cause is noble and necessary."7

These statements are very ordinary and are widely accepted by scholars and journalists as for the most part uncontroversial. Yet, do they actually hold up to critical examination? Or do they merely constitute Chomsky's second approach to the subject and are mere propaganda? My goal in this paper is to examine Canada's role in international terrorism. I will argue that rather than "participate actively in the global fight against terrorism," Canada acts as a chief supporter of international terrorism provided that it's committed by our allies. As this seems like an audacious argument which therefore demands a thorough and careful analysis in order to be as precise as possible, as well as noting the limited space available, I will focus all of my attention on one specific case. I will begin by outlining a definition of terrorism, using the terms and designations given by the Canadian government and other major sources. I will then proceed to give a brief examination of the case of Israel's invasion of Gaza in late 2008, early 2009, in order to establish it as a near-perfect example of international terrorism. Lastly, I will examine the actions and statements of Canada's major government actors to demonstrate that we offered nearly unequivocal support for this clear-cut example of terrorism in a variety of ways.

\section{WHAT IS TERRORISM?}

Although its precise meaning and applicability to modern phenomena is quite elastic in Western discussions, the definition of terrorism is given legally in many official sources. For example, Canada's 2001 'Anti-Terrorism Act' defines terrorism as:

"an act...that is committed...for a political, religious or ideological purpose... with the intention of intimidating the public...or compelling a person, a government or a domestic or an international organization to do or to refrain from doing any act and (ii) that intentionally (A) causes death or serious bodily harm to a person by the use of violence...(B) endangers a person's life...(C) causes a serious risk to the health or safety of the public." 8

The US Federal criminal code defines terrorism as:

"activities that $-(\mathrm{A})$ involve violent acts or acts dangerous to human life that (B) appear to be intended -(i) to intimidate or coerce a civilian population; (ii) to influence the policy of a government by intimidation or coercion; or (iii) to affect the conduct of a government by mass destruction, assassination, or kidnapping." 9

\footnotetext{
${ }^{6}$ Statement by the Honorable Lawrence Cannon Minister of Foreign Affairs to the General Debate of the $64^{\text {th }}$ Session of the United Nations General Assembly. September 26, 2009.

${ }^{7}$ Canada.com via CanWest News Service. "Harper urges continued battle against terrorism." September 10, 2007.

${ }^{8} \mathrm{I}$ attached the extremely long, full length definition in the back of this paper as an appendix. I attempted to synthesize its key elements into a workable definition here.

${ }^{9} 18$ U.S.C $§$ 2331: US Code- Section 2331: Definitions.
} 
A 2004 UN Security Council resolution defined an act as terrorism if:

"it is intended to cause death or serious bodily harm to civilians and non-combatants, with the purpose of intimidating a population or compelling a Government or an international organization to do or abstain from any act"10

All three of these definitions contain obvious similarities: terrorism is an intentional violent act or threat of violence that seeks to intimidate, coerce, and terrorize a population, government or international organization as a means to affect a certain political, religious or ideological end. Terrorism specialist Michael Stohl effectively parses these elements into a reasonable and concise working definition of terrorism as " $[\mathrm{t}]$ he purposeful act or the threat of the act of violence to create fear and/or compliant behavior in a victim and/or audience of the act or threat." 11 This definition makes clear the key element that separates terrorism from other acts of violence: it is violence (or threat of) with a broader purpose than the physical harm of its immediate victims.

Two questions arise at this point: 1) whether states can commit acts of terrorism, and 2) if so, how terrorism differs from other acts of international aggression. The answer to the first is quite clear considering the fact that the etymological root of the English use of the word "terrorism" and "terrorist" trace back to the "Reign of Terror" of the Jacobin and Thermidorian regimes in France. ${ }^{12}$ Further cementing this point, Stohl writes that "much of the finest analytic work on the nature of terrorism has been conducted by scholars who were primarily interested in the use of terrorism by governments." 13 The answer to the second question is given adequately by Chomsky who writes "let us give the benefit of the doubt to the [State] and its clients: if they reject the charge of aggression in the case of some act of international violence, we will take it to fall under the lesser crime of terrorism." "In sum, we are interested in Canada's association in "[t]he purposeful act or the threat of the act of violence to create fear and/or compliant behavior in a victim and/or audience of the act or threat" that is not subsumed under the title of aggression.

\section{SUPPORTING ISRAELI TERROR}

On December 27, 2008, Israeli F-16's and Apache attack helicopters launched a "surprise attack [on the Gaza Strip], in which 88 aircraft simultaneously struck 100 preplanned targets within a

\footnotetext{
${ }^{10}$ UN Security Council Resolution 1566. October 8, 2004. [Accessed: http://daccess-ddsny.un.org/doc/UNDOC/GEN/N04/542/82/PDF/N0454282.pdf?OpenElement]

${ }_{11}^{11}$ Stohl, Michael. The Politics of Terrorism. (Marcel Dekker Inc.: New York, 1988). Pg. 3.

12 Ibid. Pg. 8.

${ }^{13}$ Ibid. This includes, for example, Hannah Arendt's The Origins of Totalitarianism. US scholar Michael Walzer, who is one of the progenitors of 'just war theory' in international relations, also affirms that terrorism is a legitimate description of specific actions committed by states. See: Walzer, Michael. Arguing About War. (Yale University Press, New Haven \& London, 2004).pgs 64, 130.

${ }^{14}$ Chomsky, Noam. Pirates and Emperors, Old and New: International Terrorism in the Real World. (Between the Lines: Toronto, 2002.) pg. 121.
} 
record span of 220 seconds." 15 This first-day strike, having begun at "a day and time when the streets are very busy, particularly as children finish school,"16 "appear[ed] to have been calculated to create the greatest disruption and widespread panic among the civilian population,"17 and ratcheted up the highest one-day death toll in 60 years of Israeli-Palestinian conflict, ${ }^{18}$ killing "at least 225 people and injur[ing] more than 700."19 Israeli analyst Ron Ben Yishai referred to this strike as "shock treatment ... aimed at securing a long-term ceasefire between Hamas and Israel on terms that are favorable to Israel." ${ }^{20}$ An Israeli ground invasion followed on January 3, with attacks continuing until the declaration of a ceasefire on the 18th.

A special UN fact finding mission released a report in September 2009 which gave detailed accounts of the methods utilized by the Israeli military; methods which constitute nearperfect examples of terrorism as defined by major sources. The assault was composed of "deliberate attacks on civilians and civilian objects (individuals, whole families, houses, mosques)," ${ }^{, 1}$ government buildings, prisons, police stations, ${ }^{22}$ " 280 schools and Kindergartens," "food supply installations, water sanitation systems, concrete factories and residential houses...the result of a deliberate and systematic policy to make the daily process of living...more difficult for the civilian population." 24 The $500+$ page UN report summed itself up in clear terms:

"the Mission concludes that what occurred in just over three weeks at the end of 2008 and the beginning of 2009 was a deliberately disproportionate attack designed to punish, humiliate and terrorize a civilian population, radically diminish its local economic capacity both to work and to provide for itself, and to force upon it an ever increasing sense of dependency and vulnerability... The Mission has noted with concern public statements by Israeli officials, including senior military officials, to the effect that the use of disproportionate force, attacks on civilian population and destruction of civilian property are legitimate means to achieve Israel's military and political objectives. "25

\footnotetext{
15 Opall-Rome, Barbara. “In Gaza War Both Sides Reveal New Gear.” Defense News. January 5, 2009.

${ }^{16}$ Amnesty International. "Israel/OPT: Immediate Access to Humanitarian Workers and Observers Essential." December 31, 2008.

17 "The timing of the first Israeli attack, at 11:30 am on a week day, when children were returning from school and the streets of Gaza were crowded with people going about their daily business, appears to have been calculated to create the greatest disruption and widespread panic among the civilian population." UN "Human Rights in Palestine and Other Occupied Arab Territories: Report of the United Nations Fact Finding Mission on the Gaza Conflict.” September 15, 2009. pg. 524.

${ }^{18}$ Zakaria, Tabassum. “US Blames Hamas for Ceasefire Break With Israel.” Reuters. December 27, 2008.

${ }^{19}$ Colvin, Marie, Tony Allen-Mills and Uzi Mahnaimi. “Israeli Jets Kill 'at least 225' in strikes on Gaza.” Sunday Times. December 28, 2009.

${ }^{20}$ Entous, Adam. "Israel Kills Scores in Gaza Air Strikes." Reuters. December 27, 2008.

${ }^{21}$ UN "Human Rights in Palestine and Other Occupied Arab Territories: Report of the United Nations Fact Finding Mission on the Gaza Conflict.” September 15, 2009. pgs. 533. [Accessed: http://image.guardian.co.uk/sys-

files/Guardian/documents/2009/09/15/UNFFMGCReport.pdf]

${ }^{22}$ Ibid. pg. 103

${ }^{23}$ Ibid. pg. 23

${ }^{24}$ Ibid. pg. 525 .

${ }^{25}$.Ibid. pgs. 525-6.
} 
This description perfectly aligns with all of the official definitions of terrorism as an act "intended to cause death or serious bodily harm to civilians and non-combatants, with the purpose of intimidating a population or compelling a Government or an international organization to do or abstain from any act" participate actively in the global fight against terrorism," by "holding the perpetrators and supporters of terrorism accountable for their actions"? ${ }^{27}$ Or did Canada vigorously support Israeli terror, while using all of our diplomatic means to prevent any hint of accountability? It will become quite clear that the major voices in Canada's government pursued this latter optionin direct opposition to stated claims concerning terrorism.

Ottawa's immediate response to this initial Israeli "shock treatment" that killed "at least 225 people and injured more than 700," 28 was a statement affirming that "Israel has a clear right to defend itself against the continued rocket attacks by Palestinian militant groups which have deliberately targeted civilians." ${ }^{29}$ These words, spoken by Foreign Affairs Minister Lawrence Cannon, belay a relative truism in international affairs: nearly all crimes, now matter how horrific in nature, are according to its agents mere acts of rightful retaliation against the crimes of an adversary. For example, Vladimir Putin's 'counter-terrorist' obliteration of Grozny in 1999 which merely sought to "destroy the [Chechen] bandits and to create a sufficiently broad zone of safety" around the area, according to the Russian Defense Minister at the time. ${ }^{30}$ Or the words of Osama Bin Laden in reference to the 9/11 attack:

"The mission is to spread the word of God, not to indulge massacring people. We ourselves are the target of killings, destruction and atrocities. We are only defending ourselves. This is defensive jihad. We want to defend our people and our land. That is why I say that if we don't get security, the Americans, too would not get security."31

Cannon's support of Israeli terror persisted along similar lines. While admitting a "growing concern" about the civilian deaths caused by Israeli air strikes, he argued that "Hamas actions that deliberately and constantly target civilians are the principal cause of these unfortunate events... [f] irst and foremost those rocket attacks must stop",32 While few dispute that Israel has a right to defend itself, Cannon explicitly supported ongoing Israeli terrorism that targeted civilians on a large scale - on a magnitude that puts any conceivable Palestinian rocket

\footnotetext{
${ }^{26}$ UN Security Council Resolution 1566. October 8, 2004. [Accessed: http://daccess-ddsny.un.org/doc/UNDOC/GEN/N04/542/82/PDF/N0454282.pdf?OpenElement]

${ }^{27}$ Both Israel and Canada rejected the notion that the Israeli invasion was an act of aggression. As we will see, all of Canada's major voices in government referred to the invasion as an act of 'self defence' and instead charged Hamas with aggression. On this basis, Israel's actions will be not be treated as acts of international violence and aggression but will be seen as the 'lesser crime' of terrorism.

${ }^{28}$ Colvin, Marie, Tony Allen-Mills and Uzi Mahnaimi. "Israeli Jets Kill 'at least 225' in strikes on Gaza." Sunday Times. December 28, 2009.

${ }^{29}$ CBC. "International Community Calls for end to violence in Middle East." December 27, 2008 and Brosnki, Carl and Keith Jones. "Canada's Government and Opposition trumpet Israel's 'right' to wage endless war in Gaza." Global Research. January 11, 2009.

${ }^{30}$ Gordon, Michael R. "Chechens Flee Russian Bombs by Thousands.” New York Times. September $27,1999$.

${ }^{31}$ MSNBC. "Al-Qaida: Timeline of Statements." Bin Laden's statement is from November 7, 2001.

32 Globe and Mail. "Gaza: New Years Day Diplomacy.” January 1, 2009.
} 
attack against civilians to shame ${ }^{33}$ - as part of this 'clear right to self defense.' Even more absurdly, he based his support of ongoing Israeli terrorism that targeted civilians on the fact that Hamas had done so as well. No serious mainstream commentator in the West would ever affirm support for Palestinian terrorist atrocities as part of their 'right to self defense' against Israeli terrorism; yet the inverse is repeatedly supported as an unfortunate, yet fully just 'right of self defense', by Canadian political leaders and intellectual opinion.

Liberal leader Michael Ignatieff was similarly assistive of Israeli terrorism, insisting on January $8^{\text {th }}, 2009$ that "Israel is justified in continuing military operations," and that "[w]e affirm Israel's right to defend itself against such attacks." ${ }^{34}$ In accordance with his status as a world renowned human rights expert, however, Ignatieff made sure to take a hard-line against the wrong sort of terror, firmly stating that he "unequivocally condemns the rocket attacks launched by Hamas against Israeli civilians," 35 (which killed a total of three civilians.) ${ }^{36}$ A similarly unequivocal condemnation of continuing Israeli terrorism that in sum killed around 800 civilians (of which 318 were minors) ${ }^{37}$ was not forthcoming, as Ignatieff further declared his approval of the ongoing Israeli bombardment of Gaza. "Canada has to support the right of a democratic country to defend itself," he claimed, cynically blaming the high civilian casualties in Gaza on Hamas "for sheltering among civilian populations." 38 In an attempt to distance himself and the country from any hint of support for agents of terrorism, Ignatieff affirmed that "Canada can't touch Hamas with a 10-foot pole." 39 It's clear that these same standards don't apply to the terrorism Ignatieff approves of.

The Canadian media was notably uncritical of the bipartisan consensus in support of Israeli terror. In an editorial in the National Post, for example, Ignatieff's comments were celebrated as "sensible remarks," noting that "we [at the Post] worried about the former Harvard professor," after "he spuriously declared to a Quebec audience that Israel had perpetrated a "war crime' in the Lebanese town of Qana," in 2006. "This time", they note, "Mr. Ignatieff is supporting Israel four-square." 41 The Post, "gratified to see that these facts have not escaped the notice of our country's leaders," underscored Ignatieff's authentic new understanding that "the war in Gaza is not a morally complicated event," considering that "[o]n one side is a terrorist group," while "[o]n the other side is a democratic Canadian ally that is seeking to minimize civilian casualties as it fights back against ruthless killers." 42 Pravda would certainly be impressed.

\footnotetext{
${ }^{33}$ In the three years after Israel's disengagement from Gaza, 11 Israeli's have been killed by rocket fire (the notoriously inaccurate Qassam rockets are reputed to have a kill-ratio of $0.4 \%$ ); in this same period the Israeli Army killed 1250 Palestinians in Gaza; 222 of them children. (This does not count the casualties suffered during the 08-09 war) For above figures, see: "Israel's Bombardment of Gaza is not self defence- it's a war crime." Sunday Times. January 11, 2009; Levine, Mark. "Who Will Save Israel From Itself?” Al Jazeera. January 13, 2009.

${ }^{34}$ Transcript of Michael Igantieff's responses to questions posed during a town hall meeting in Halifax on January 8 , 2009. Accessed Via: Canadian Jewish News. "Liberal Leader Weighs in On Gaza."

${ }^{35}$ Vancouver Sun. "Harper Steers Clear of Mideast Controversy." January 6, 2009.

${ }^{36}$ B'Tselem. "Operation Cast Lead, 27 Dec. '08 to 18 Jan. '09."

${ }^{37}$ Ibid.

${ }^{38}$ The Star. "Ignatieff says Israel must be allowed to defend itself." January 8, 2009.

${ }^{39}$ Ibid.

40 "Moral Clarity on the Middle East." National Post. January 10, 2009.

${ }^{41}$ Ibid.

${ }^{4}$ Ibid.
} 
Canadian support for Israeli terror also includes a long history of military exports used in aerial bombardments of civilian centers. In a study by the Coalition to Oppose the Arms Trade, Richard Sanders writes that there are "more than 50 Canadian military exporters that have supplied a wide range of essential components and/or services for three major US weapons systems that are used by the Israeli Air Force: the F-15, F-16 and AH-64." ${ }^{43}$ Sanders notes that "[t]hese fighter/bomber aircraft and helicopter attack gunships were the main varieties of weapons systems employed by Israel during the recent aerial bombardments of Gaza."44 It is very possible that Canadian-made military components were used in this subsequent example.

On January 6, when Israeli forces bombed a UN run school "packed with hundreds of people who had fled the fighting" 45 killing 42, many of them women and children, and injuring 55 others, ${ }^{46}$ Deputy Foreign Minister Peter Kent told reporters that "Hamas bears a terrible responsibility for this and for the wider deepening humanitarian tragedy. The burden of responsibility is on Hamas to stop its terrorist rocketing of Israel. ${ }^{, 47}$ Kent again reiterated the doctrinal impossibility of Israeli terrorism, maintaining that "[w]e do know that it is the Hamas practice to use civilian infrastructure and civilian population as shields for their terrorist activity and they certainly bear the burden of responsibility for behaving that way again here."48 The seeming absurdity of Kent's comments were not lost on the news organization Reuters, who noted that Canada "blam[ing] the Palestinian militant group Hamas for the deaths of more than 40 civilians who were killed by Israeli shells" amounted to "some of the most hard-line comments by any leading western nation." 49

In fact, Canada stood alone in the world on a few occasions in their support for Israeli terror. On January 12, 2009, with the death toll "surpassing 900, including nearly 400 women and children," 50 Canada was the only member of the 47 -seat Human Rights Council to vote against a resolution condemning the Israeli military offensive in Gaza. The resolution called for "urgent international action to put an immediate end" to the "ongoing Israeli military operation... which has resulted in massive violations of human rights... and systematic destruction of the Palestinian infrastructure." ${ }^{, 51}$ Following established doctrinal patterns, Canada reiterated its support for Israeli terrorism with the Foreign Affairs Department asserting that the "deeply flawed...resolution...ignored a state's legitimate right to self-defence.",52

Canadian support of terrorism continued afterwards at the UN, where "strong, principled action" made sure that agents of terror escaped any intimation of legal scrutiny or accountability.

\footnotetext{
43 Sanders, Richard. "Canadian Military Exports to Israel.” Coalition to Oppose the Arms Trade.

44 Ibid.

${ }^{45}$ McGreal, Chris and Hazem Balousha. "Gaza's Day of Carnage- 40 dead as Israelis bomb two UN schools." The Guardian. January 7, 2009.

${ }^{46}$ Macdonald, Alastair. “Israel Pounds Gaza Again.” Reuters. January 7, 2009.

${ }^{47}$ Reuters. "Hamas Responsible For Deadly Gaza Attack: Canada" January 6, 2009.

${ }^{48}$ CTV News. "Besieged Canadians await evacuation from Gaza."

${ }^{49}$ Reuters. "Hamas Responsible For Deadly Gaza Attack: Canada” January 6, 2009.

${ }^{50}$ Agence France-Presse. "UN rights council condemns Israeli offensive in Gaza." January 12, 2009.

${ }^{51}$ UN General Assembly, Human Rights Council. "The Grave Violations of Human Rights in the Occupied Palestinian Territory particularly due to the recent Israeli military attack against the occupied Gaza Strip." January 12, 2009. [http://unispal.un.org/unispal.nsf/0/a8a783acb5d0c6b88525753c0071f427?OpenDocument]

${ }^{52}$ Campion-Smith, Bruce and Les Whittington. "Canada Votes Alone for Israel." The Star. January 13, 2009.
} 
Canada was among a tiny minority in the world that twice voted against an investigation into "serious violations of international humanitarian and human rights law" committed by both Israel and the Palestinians during the Gaza conflict. ${ }^{53}$ The first resolution was passed in late November 2009 with a vote of 114 in favor and 18 against, with Canada combining with the US, Israel and a littering of European nations in opposition. By the time the second resolution was passed in February of 2010 (which was a follow-up on the first), the votes opposed to merely investigating possible war crimes dwindled to only seven nations (Canada, Israel, United States, Micronesia, Nauru, Panama, Macedonia). ${ }^{54}$ It seems that Lawrence Cannon's claim that "Canada is committed to...holding the perpetrators and supporters of terrorism accountable for their actions" has little basis in reality, if we are to consider Canada's actions at the UN.

\section{CONCLUSIONS}

We have seen how the official definitions of terrorism have obvious applicability to Israeli actions in the case described. We have also witnessed Canada's rigorous diplomatic support for these deeds by means of official public statements of approval and justification, the export of arms utilized for these purposes, voting against resolutions calling for an end to the ongoing actions, as well as voting against resolutions that would promote accountability for such actions. Throughout, Canada stands firmly in support of actions which can only be described as terrorism if the term is to have any real meaning whatsoever. This leads to some rather disturbing conclusions regarding Canadian foreign policy as well as the academic study of terrorism.

When it comes to the terrorism of our friends in the international sphere, government leaders and the press seem to embrace the propagandistic approach that was outlined earlier: the concept of 'terrorism' is used to describe acts worthy of moral outrage and unequivocal condemnation when performed by our enemies, yet similarly transparent acts of terrorism by our friends are quickly revised into acts of responsible self defense by a democratic ally. This mode of thought seems to be widely accepted as valid by government actors and their ostensible critics, and thus faces little to no scrutiny. Unless it is confronted and openly criticized for its obvious intellectual and moral incongruities, it will continue to persist- with egregious consequences for the victims.

Furthermore, an embrace of the propagandistic approach could easily describe the overwhelming majority of academic studies on terrorism, in which the focus is purely on the 'terror' of ostensible 'enemies', with little recognition given to the idea that Western states may play a role- even more, a major role- in both supporting and carrying out acts of terrorism. Shifting our understanding of terrorism to incorporate our actions as well as theirs entails a momentous intellectual paradigm shift that opens the field up to an enormous range of new and rather unsettling questions. In the West's 'age of terror', the label of 'terrorist' or any connection to terrorism serves to immediately morally discredit any person or an institution. With this shift in perspective, how then are we to respond to the 'War on Terror'? To our own institutions

\footnotetext{
${ }^{53}$ UN General Assembly. "By Recorded Vote, General Assembly Urges Israel, Palestinians to Conduct Credible, Independent Investigations into Alleged War Crimes in Gaza.” November 5, 2009.

${ }^{54}$ UN General Assembly. "General Assembly Requests Secretary-General to Submit Further Report On Investigations into Violations During Gaza Conflict.” February 26, 2010.
} 
which have clear links to terrorism? While these questions are far beyond the scope of this paper, it is clear that they must begin to be discussed.

In sum, Canada's official stance of harshly disavowing terrorism when committed by Hamas, while simultaneously supporting the justice of terrorism when committed by Israel, should cause some pause in accepting the official narrative of Canada's "noble and necessary" struggle against terror. If we truly aim to 'confront and defeat' terrorism- a praiseworthy aim, if taken seriously- we may begin with a simple step: stop supporting it. 


\section{BIBLIOGRAPHY}

Agence France-Presse. "UN rights council condemns Israeli offensive in Gaza." January 12, 2009.

Amnesty International. "Israel/OPT: Immediate Access to Humanitarian Workers and Observers Essential." December 31, 2008.

B’Tselem. “Operation Cast Lead, 27 Dec. '08, to 18 Jan. '09.”

Brosnki, Carl and Keith Jones. "Canada's Government and Opposition trumpet Israel's 'right' to wage endless war in Gaza." Global Research. January 11, 2009.

Campion-Smith, Bruce and Whittington, Les. "Canada Votes Alone for Israel." The Star. January 13, 2009.

Canada.com via CanWest News Service. "Harper urges continued battle against terrorism." September 10, 2007.

Cannon, Lawrence. "Walking Out on Iran.” National Post. September 24, 2009.

Canadian Jewish News. "Liberal Leader Weighs in On Gaza.” January 8, 2009.

CBC. "International Community Calls for end to violence in Middle East." December 27, 2008

Chomsky, Noam. Pirates and Emperors, Old and New: International Terrorism in the Real World. (Between the Lines: Toronto, 2002.)

Colvin, Marie, Tony Allen-Mills and Uzi Mahnaimi. "Israeli Jets Kill 'at least 225' in strikes on Gaza." Sunday Times. December 28, 2009.

CTV News. "Besieged Canadians await evacuation from Gaza."

Entous, Adam. "Israel Kills Scores in Gaza Air Strikes." Reuters. December 27, 2008.

Foreign Affairs and International Trade Canada.

[http://www.international.gc.ca/crime/terrorism-

terrorisme.aspx?menu_id $=30 \&$ menu $=\mathrm{R}]$

Globe and Mail. "Gaza: New Years Day Diplomacy.” January 1, 2009.

Gordon, Michael R. "Chechens Flee Russian Bombs by Thousands." New York Times. September 27, 1999.

Greenwald, Glenn. "Terrorism: the most meaningless and manipulated word." Salon.com February 19, 2010. 
[http://www.salon.com/news/opinion/glenn_greenwald/2010/02/19/terrorism]

Ignatieff, Michael. The Lesser Evil: Political Ethics in an Age of Terror. (Toronto: Penguin Books, 2004).

Levine, Mark. "Who Will Save Israel From Itself?” Al Jazeera. January 13, 2009.

Macdonald, Alastair. “Israel Pounds Gaza Again.” Reuters. January 7, 2009.

McGreal, Chris and Hazem Balousha. "Gaza's Day of Carnage- 40 dead as Israelis bomb two UN schools." The Guardian. January 7, 2009.

Morden, Reid. "Spies Not Soothsayers: Canadian Intelligence After 9/11." Commentary No. 85. Fall 2003.[Accessed: http://www.csis-scrs.gc.ca/pblctns/cmmntr/cm85eng.asp]

MSNBC. "Al-Qaida: Timeline of Statements."

[http://www.msnbc.msn.com/id/4686034/ns/world_news-hunt_for_alqaida//]

National Post. "Moral Clarity on the Middle East." January 10, 2009.

Opall-Rome, Barbara. “In Gaza War Both Sides Reveal New Gear.” Defense News. January 5, 2009.

Orwell, George. "Notes on Nationalism." In The Decline of the English Murder (Penguin Books: Harmondsworth, 1946.) Pg. 165.

Reuters. "Hamas Responsible For Deadly Gaza Attack: Canada" January 6, 2009.

Sanders, Richard. "Canadian Military Exports to Israel." Coalition to Oppose the Arms Trade. [http://coat.ncf.ca/ARMX/cansec/Tables.htm]

The Star. "Ignatieff says Israel must be allowed to defend itself." January 8, 2009.

Statement by the Honorable Lawrence Cannon Minister of Foreign Affairs to the General Debate of the $64^{\text {th }}$ Session of the United Nations General Assembly. September 26, 2009. [Accessed: http://www.canadainternational.gc.ca/prmny-mponu/canada_uncanada_onu/statements-declarations/general_assembly-assembleegenerale/26.09.2009\%20Cannon\%2064th\%20Session-64e\%20Session.aspx]

Stohl, Michael. The Politics of Terrorism. (Marcel Dekker Inc.: New York, 1988).

Sunday Times "Israel's Bombardment of Gaza is not self defence- it's a war crime.". January 11, 2009.

UN General Assembly. "By Recorded Vote, General Assembly Urges Israel, Palestinians to Conduct Credible, Independent Investigations into Alleged War Crimes in 
Gaza.” November 5, 2009.

UN General Assembly, Human Rights Council. "The Grave Violations of Human Rights in the Occupied Palestinian Territory particularly due to the recent Israeli military attack against the occupied Gaza Strip.” January 12, 2009. [http://unispal.un.org/unispal.nsf/0/a8a783acb5d0c6b88525753c0071f427?Ope nDocument]

UN "Human Rights in Palestine and Other Occupied Arab Territories: Report of the United Nations Fact Finding Mission on the Gaza Conflict." September 15, 2009. pgs. 525-6. [Accessed: http://image.guardian.co.uk/sysfiles/Guardian/documents/2009/09/15/UNFFMGCReport.pdf]

UN Security Council Resolution 1566. October 8, 2004. [Accessed: http://daccess-ddsny.un.org/doc/UNDOC/GEN/N04/542/82/PDF/N0454282.pdf?OpenElement]

18 U.S.C. $§ 2331$ : US Code - Section 2331: Definitions [Accessed: http://codes.lp.findlaw.com/uscode/18/I/113B/2331]

Vancouver Sun. “Harper Steers Clear of Mideast Controversy.” January 6, 2009.

Zakaria, Tabassum. "US Blames Hamas for Ceasefire Break With Israel.” Reuters. December 27, 2008.

\section{APPENDIX}

ANTI-TERRORISM ACT'S DEFINTION OF TERRORISM (2002) 
"terrorist activity" means:

(b) an act or omission, in or outside Canada,

(i) that is committed

(A) in whole or in part for a political, religious or ideological purpose, objective or cause, and

(B) in whole or in part with the intention of intimidating the public, or a segment of the public, with regard to its security, including its economic security, or compelling a person, a government or a domestic or an international organization to do or to refrain from doing any act, whether the public or the person, government or organization is inside or outside Canada, and

(ii) that intentionally

(A) causes death or serious bodily harm to a person by the use of violence,

(B) endangers a person's life,

(C) causes a serious risk to the health or safety of the public or any segment of the public,

(D) causes substantial property damage, whether to public or private property, if causing such damage is likely to result in the conduct or harm referred to in any of clauses (A) to (C), or (E) causes serious interference with or serious disruption of an essential service, facility or system, whether public or private, other than as a result of advocacy, protest, dissent or stoppage of work that is not intended to result in the conduct or harm referred to in any of clauses (A) to (C),

and includes a conspiracy, attempt or threat to commit any such act or omission, or being an accessory after the fact or counselling in relation to any such act or omission, but, for greater certainty, does not include an act or omission that is committed during an armed conflict and that, at the time and in the place of its commission, is in accordance with customary international law or conventional international law applicable to the conflict, or the activities undertaken by military forces of a state in the exercise of their official duties, to the extent that those activities are governed by other rules of international law. 